\title{
Analysis of the Profile of non-profit Organizations Receiving Funding by a Microfinance Institution: the Case of Burundi
}

\author{
Marie-Goreth Nduwayo \\ University of Quebec at Montréal, Canada \\ Michel Sayumwe (Corresponding author) \\ University of Quebec at Montréal, Canada \\ E-mail: sayumwe.michel@uqam.ca
}

Received: April 22, 2018 Accepted: May 11, 2018 Published: July 25, 2018

doi:10.5296/ber.v8i3.13421ＵRL: https://doi.org/10.5296/ber.v8i3.13421

\begin{abstract}
In this study, we analyze the profile of burundian non profit organizations (NPOs) receiving funding from a microfinance institution. We focus on the concept of strategic alignment as developed by Henderson and Venkatram (1999) which assumes that the corporate performance is related to the management skills. We analyze the modes of operation of Burundian NPOs which benefit from microcredit. We observe that they reflect an appropriate financing strategy. In fact, our study concludes that the income-generating activity flows a well-defined profile that ensures an adaptation for the NPOs. While the microcredit institution has a financial role, it also contributes to satisfy basic needs for survival of the NPOs members.
\end{abstract}

Keywords: Strategic alignment, Microfinance institution, Non profit organization, Income generating activity, Burundi, Microcredit

\section{Introduction}

Evolution in the conceptualization of organizations and difficulties in measuring their goals have led to many criticisms of the rational model and the development of other performance models. In this paper, we attach great importance to the relationship established between the organization and its environment. In this article, we provide explanations for the variables that describe burundian NPOs. We also explain the differences between individuals from the 
point of view of this or that variable. Data analysis and interpretation focus on the cloud of variables. In interpretation, we focus on the sense that profiles deviate from the average profile.

To explain the profile indicators of non-profit organizations (NPOs) that benefit from microcredit in Burundi, we base on five main variables and the modalities they take. We judge that the individuals having adopted the modalities of the same variable resemble and have the same profiles. We thus complete the data resulting from a factorial analysis by a typology of the individuals in class such that the individuals of the same class resemble each other as much as possible, and those belonging to two different classes are very differentiated. Classification methods therefore seek to identify the overall similarities between individuals and classify these last individuals in class categories according to their commonality.

This article is structured as follows. The second section will deal with the theoretical framework and the literature review, and the third section with the methodological framework. In the fourth section, we present the results of the research, discuss them in the fifth section and conclude with section 6 .

\section{Theoretical Framework and Literature Review}

The concept of strategic alignment of Henderson and Venkatraman (1999) is based on the hypothesis assuming that economic performance is directly related to management skills. The latter must confront the position of an organization in the field of competition and the design of an appropriate administrative structure to take charge of its execution. This assumption is consistent with the generally accepted axiom that strategic choices internally and externally must be consistent (Theuvsen, 2004).

The organizational effectiveness of Burundian NPOs benefiting from microcredit is therefore explained by two variants of strategic alignment that highlight the interaction between the different dimensions. Adaptation consists on the one hand, that the necessary resources are accessible to reach the corporate objectives. However, the goals of Burundian NPOs benefiting from microcredit are directly related to microfinance institutions. The same adjustment is noticeable with the internal integration of these nonprofits on the other hand. Indeed, the value of human relations for example requires a certain strategy that leads to the achievement of the goals as it is mentioned in the table below.

Table 1. Models of Organizational Effectiveness of NPOs Benefiting from Microcredit

\begin{tabular}{|l|l|}
\hline Variant of strategic alignment & $\begin{array}{l}\text { Organizational Effectiveness Model of } \\
\text { NPOs Benefiting from Microcredit }\end{array}$ \\
\hline Adaptation & Goal Achievement Model \\
\hline Internal integration & Internal organization model \\
\hline Adaptation & Model of Resource Acquisition \\
\hline Internal integration & Model of human relations \\
\hline Adaptation, Internal integration & Political Model \\
\hline Adaptation & Model of legitimacy \\
\hline
\end{tabular}

Source: Authors from the theoretical model of Henderson and Venkatraman (1999) 
The six models are ubiquitous in every NPO for its survival. Adaptation means that the organization must acquire resources to ensure its sustainability and must be able to function in accordance with the requirements of its financial environment. The "Goals Achievement" model, for example, refers to the concepts of efficiency (goal of meeting primary needs) and efficiency (internal organization). The "Human Relations" model is a reflection of the value system of NPOs who benefit from microcredits, which gives them meaning. Then, the model of "internal organization" refers to the "technical core of the organization" (Sicotte et al., 1999).

Many management tools shed light on the key dimensions of performance that need attention. But a reflection in the choice of an indicator is very necessary so that the chosen indicator makes sense for the whole organization. Bureau et al (2010) suggest that a bad choice of indicators can lead to perverse effects, that is, behaviors that go against the intended purpose. And if there are too many, the indicators can move away from the lived reality. Moreover, according to these authors, it is also necessary to ensure that the indicator measures the dimension in question and not its consequence. There are two types of indicators (Kaplan and Norton, 2001b):

- Objective indicators to monitor the achievement of strategic objectives;

- Indicators of action variables and action plans that provide information on the means used to achieve the strategic objectives.

Around the world, there have been surveys of business activities that have been conducted. Most often, these surveys concern a few industrial sectors. The ultimate goal is to disaggregate the activities identified into industries for national accounts purposes. However, branch surveys extend to trade, transport and other specific sectors. But so far, no reflection on the activities of non-profit organizations has been conducted. In some cases, priority even given to funding, while the advice and participation aspects are not very important.

When analyzing the activities of non-profit boards or committees, Middleton (1987) argued that in large corporations, committees are more involved in policy making and less involved in operational activities. Smith and Lipsky (1993) noted that a non-profit organization often develops through good governance. Saidel (1989) concludes that the board of directors of a non-profit organization is not passive in its negotiating relationship with the government. On the contrary, it plays several roles including helping the organization to develop proposals for a possible application for government grants for example. From the point of view of resources, the board of directors reinforces the interdependence between all the actors. It is essential for the organization because it discusses the impact of funding, defines priorities and thus contributes to the preservation of the autonomy of the non-profit organization. Unfortunately, the activities of members of a non-profit organization have never been studied.

Williamson (2002) is credited with the first study of the Coase problem (1995), which analyses the role of coordination in determining the firm's optimal size. Research on group decisions has also shown that the size of groups depends on the motivation of the members as well as the coordination and quality of the decision-making process. In short, the authors 
cited above and all the theorists of the firm locate the influence of size in the internal coordination of the company.

Small and medium-sized enterprises, for example, have more horizontal managerial structures and greater flexibility than larger firms (McAdam and McKeown, 1999). In addition, they are more client-oriented, less complex, and have better communication because of informal relationships (Cagliano et al., 2001). They are also more likely to implement innovative practices in their work (Walley, 2000).

In general, the socio-economic characteristics of companies have a significant explanatory power on their performance. For Schumpeter (1935), for example, small businesses are a great source of innovation. The author explains that small or medium-sized businesses enable organizational efficiency. The size of an organization is therefore an important factor, both in the literature on management control. In terms of performance management specifically, Sila (2007) argues that companies of different sizes have distinctive characteristics that can have different effects on their performance.

The article of Lawrence and Lorsch (1967) suggest that different environments correspond to different organizational structures. Taking into account the structures, these authors proposed that the highest levels of performance were observed in companies in which each subsystem had an organization adapted to the requirements of the environment it was facing. Thus, for example, a stable environment corresponds to a greater focus of very specific tasks and a more formal organization. As a result, the structure of each business activity corresponds to a specific environment it faces.

Mintzberg (1982) also considers that the structure of an organization is related to the nature of its environment. In general, contingency theories also recognize that all organizations are different and that there are no formal structures that are ideal (Theuvsen, 2004). Thus, the contingency principle as defined by Lawrence (1993) clearly explains the effects of structure on organizational effectiveness. According to them, there is no structure that is the best but rather different structures that are best in different situations. In short, the ability to adapt depends on the ability of an organization to modify its structure.

Regarding the framework, we start from the fact that in management control research, three approaches have been identified to evaluate organizational performance (Kihn, 2005). These are the accounting-based approach, the goal-centered approach and the behavioral approach. In the accounting approach, performance is measured on the basis of accounting information such as profitability, liquidity and solvency ratios from the financial statements. For economists, financial analysts and organizational leaders, efficiency is often synonymous with financial sustainability (Herman and Renz, 2004).

In the goal-centered approach, it is usually the performance of an organization, or a sub-unit of the organization (such as a working group or project), which is evaluated by compared to the objectives. All objectives must be manageable and clearly defined (Gauzente, 2000). While the measurement tools developed in the framework of the accounting approach are based on financial indicators, those that are part of the goal-based approach focus on the 
evaluation of the achievement of non-financial (operational) objectives and financial. The self-assessment of the performance thus consists in a comparison between the real performance and the predictive performance of several dimensions of the organizational activity (Kihn, 2005).

In the same vein, Atkinson and Waterhouse (1997) vision is part of coalition analysis. They classify stakeholders according to two main groups, external (environmental stakeholders: customers, suppliers, the community) and internal ones (process stakeholders: employees and shareholders). They consider that the first objectives to reach are those of the owners. Then, as the coalition analysis suggests, they observe how other stakeholders work together to achieve these primary goals. In exchange for this collaboration, stakeholders have expectations of the organization that these authors call secondary goals.

In the behavioral approach developed by psychologists, it is individual performance that is generally considered as a determinant of organizational effectiveness. The performance of groups of individuals has also been studied in this approach. The latter is based on the principle that performance can only be achieved through the behavior of members of the organization (Herman and Renz, 2004). Regarding the level of analysis, Otley (1980) states that performance can be studied at the micro or macro level, or both. The level of micro analysis refers to the analysis of individual behaviors, while the level of macro analysis refers to the study of performance at the level of the organization or sector.

\section{Methodological Framework}

Two main approaches are common in Management research, namely the variable approach and the case-by-case approach. Of course, other approaches exist, but this opposition constitutes the two extremities of a reference axis ranging from studies on very large samples to studies of one to a few cases. Variable-centered studies are often equated with deductive and quantitative methods (Gavard-Perret et al., 2012, Ghauri and Grønhaug, 2002). However, inductive and qualitative methods focused on variables also exist (Thiétart, 1999).

Our variable-centered research approach is based on the premise that empirical observations are partial or impure representations of underlying theoretical principles. Most of the time, this approach aims to test hypotheses derived from scientific theories.

For survey processing, statistica software was used. After coding the variables, the final table of the variables submitted to the PCA, the AFC and the ACM includes 150 rows (associations) and 19 columns (variables).

Table 2. List of variables and their modalities

\begin{tabular}{|c|c|c|c|c|c|c|c|}
\hline & Modality 1 & Modality 2 & Modality 3 & Modality 4 & Modality 5 & Modality 6 & Modality 7 \\
\hline 1. Main objective & $\begin{array}{l}\text { 1. Social } \\
\text { Assistance }\end{array}$ & $\begin{array}{l}2=\text { Financial } \\
\text { Assistance }\end{array}$ & $\begin{array}{l}3=\text { Production of } \\
\text { goods and } \\
\text { services }\end{array}$ & $\begin{array}{l}4=\text { Other (to } \\
\text { be specified) }\end{array}$ & & & \\
\hline 2. Activity Sector & 1=Agriculture & $2=$ Commerce & $\begin{array}{l}3=\text { Mutual aid } \\
\text { and solidarity }\end{array}$ & & & & \\
\hline 3. Creation Date & $\begin{array}{ll}1= & \text { Before } \\
2000 & \end{array}$ & $2=2000$ & $3=2001-2005$ & $4=2006-2007$ & $5=2008-2009$ & $6=2010$ & $7=2011$ \\
\hline
\end{tabular}




\begin{tabular}{|c|c|c|c|c|c|c|c|}
\hline $\begin{array}{l}\text { 4.Age of the NPO } \\
\text { recodified }\end{array}$ & $1=16-24$ years & $2=15$ years & $3=10-14$ years & $4=8-9$ years & $5=6$ to 7 years & $6=5$ years & $7=4$ years \\
\hline $\begin{array}{l}\text { 5. Age of the } \\
\text { recodified } \\
\text { respondent }\end{array}$ & $\begin{array}{l}25=21 \text { to } 25 \\
\text { years }\end{array}$ & $\begin{array}{l}30=26 \text { to } 30 \\
\text { years }\end{array}$ & $\begin{array}{l}45=31-\text { to } 45 \\
\text { years }\end{array}$ & $\begin{array}{l}55=46 \text { to } 55 \\
\text { years }\end{array}$ & $\begin{array}{l}65=56 \text { to } 65 \\
\text { years }\end{array}$ & & \\
\hline $\begin{array}{l}\text { 6.Number of men } \\
\text { recodified }\end{array}$ & $5=0$ to 5 years & $\begin{array}{l}10=6 \text { to } 10 \\
\text { years }\end{array}$ & $\begin{array}{l}20=11-\text { to } 20 \\
\text { years }\end{array}$ & $\begin{array}{l}30=21 \text { to } 30 \\
\text { years }\end{array}$ & $\begin{array}{l}31=31 \text { and } \\
\text { over }\end{array}$ & & \\
\hline $\begin{array}{l}\text { 7.Number of } \\
\text { women recodified }\end{array}$ & $5=0$ to 5 years & $\begin{array}{l}10=6 \text { to } 10 \\
\text { years }\end{array}$ & $\begin{array}{l}20=11 \text { to } 20 \\
\text { years }\end{array}$ & $\begin{array}{l}30=21 \text { to } 30 \\
\text { years }\end{array}$ & $\begin{array}{l}31=31 \text { and } \\
\text { over }\end{array}$ & & \\
\hline $\begin{array}{l}\text { 8.Total recodified } \\
\text { members }\end{array}$ & $5=0$ to 5 years & $\begin{array}{l}10=6 \text { to } 10 \\
\text { years }\end{array}$ & $\begin{array}{l}20=11 \text { to } 20 \\
\text { years }\end{array}$ & $\begin{array}{l}30=21 \text { to } 30 \\
\text { years }\end{array}$ & $\begin{array}{l}31=31 \text { and } \\
\text { over }\end{array}$ & & \\
\hline $\begin{array}{l}\text { 9.Links between } \\
\text { members }\end{array}$ & $\begin{array}{l}\text { 1=Professiona } \\
1\end{array}$ & $\begin{array}{l}2=\quad \text { Same } \\
\text { origine }\end{array}$ & $\begin{array}{l}3=\text { Same } \\
\text { residence area }\end{array}$ & 4=Familial & $\begin{array}{l}31=31 \text { and } \\
\text { over }\end{array}$ & $6=$ Other & \\
\hline $\begin{array}{l}\text { 10. Sex of the } \\
\text { respondent }\end{array}$ & $1=$ Man & $2=$ Woman & & & & & \\
\hline 11. Region & $1=$ South & $2=$ East & $3=$ Centre & 4=North & $5=$ West & & \\
\hline 12. Schooling & $\begin{array}{l}\text { 1=Any } \\
\text { schooling }\end{array}$ & $\begin{array}{l}\text { 2=Elementary } \\
\text { School }\end{array}$ & $\begin{array}{l}3=\text { High } \\
\text { school-first } \\
\text { cycle }\end{array}$ & $\begin{array}{l}\text { 4=High } \\
\text { school-second } \\
\text { cycle }\end{array}$ & 5=Bachelor & & \\
\hline $\begin{array}{l}\text { 13. Respondent } \\
\text { activity }\end{array}$ & 1=Agriculture & $2=$ Commerce & $3=$ Couture & 4=Education & $\begin{array}{l}5=\text { Motorcycle } \\
\text { driver }\end{array}$ & $\begin{array}{l}6 \\
\text { Hairdressing }\end{array}$ & $7=$ Driver \\
\hline 14. Other activity & $\begin{array}{l}1=\text { Any other } \\
\text { activity }\end{array}$ & $2=$ Agriculture & $\begin{array}{l}3=\text { Trade and } \\
\text { crafts }\end{array}$ & $\begin{array}{l}4=\text { Other (To } \\
\text { be specified) }\end{array}$ & & & \\
\hline $\begin{array}{l}\text { 15. Activity } \\
\text { Diversification }\end{array}$ & $\begin{array}{l}\text { 1=Agriculture } \\
\text { only }\end{array}$ & $\begin{array}{l}2=\text { Agriculture } \\
\text { and } \\
\text { Commerce }\end{array}$ & $\begin{array}{l}3=\text { Agriculture- } \\
\text { breeding, crafts } \\
\text { or hairdressing }\end{array}$ & $\begin{array}{l}4=\text { Business } \\
\text { only }\end{array}$ & $\begin{array}{l}5=\text { Commerce } \\
+ \text { agriculture }\end{array}$ & $\begin{array}{l}6=\text { Commerce } \\
+ \text { other }\end{array}$ & $\begin{array}{l}7=\text { Other } \\
\text { combinaison }\end{array}$ \\
\hline $\begin{array}{l}\text { 16. Type of } \\
\text { lending MFI }\end{array}$ & $\begin{array}{l}\text { 1=Cooperativ } \\
\text { e of savings } \\
\text { and credit }\end{array}$ & $\begin{array}{l}\text { 2=Microcredi } \\
\text { t Program }\end{array}$ & $\begin{array}{l}3= \\
\text { Microfinance } \\
\text { Company }\end{array}$ & & & & \\
\hline $\begin{array}{l}\text { 17. Residence } \\
\text { Area }\end{array}$ & $1=$ Urban & $2=$ Rural & & & & & \\
\hline $\begin{array}{l}18 . \quad \text { Meetings } \\
\text { frequency }\end{array}$ & $\begin{array}{l}1=\text { Any } \\
\text { Meeting }\end{array}$ & 2=Weekly & 4=Fortnight & 4=Monthly & $5=$ Irregular & & \\
\hline 19. Warranty & $\begin{array}{l}\text { 1. Joint } \\
\text { Guaranty }\end{array}$ & 2=Mortgage & $3=$ Guaranty & 4=Wage & $5=$ Other & $6=\mathrm{NA}$ & \\
\hline
\end{tabular}

Source: Authors from survey questionnaire variables

Nineteen variables totaling 84 modalities were selected for the PCA (34 modalities) and the ACM (50 modalities) as mentioned above.

We adopt principal component analysis and multiple correspondence analysis as statistical methods to analyze our data. The first use of the database is to test the whole of the database, the significance of the correlations suggested by the analysis in principal components. To analyze the quantitative data, we make a "Principal Component Analysis (PCA)" which is an exploratory technique starting from a database with $\mathrm{n}$ observations and $\mathrm{p}$ variables, all quantitative. We thus start from a database with 150 observations and four quantitative variables. The PCA allows us to make an automatic classification and to develop a typology of NPOs that benefit from microcredit in Burundi. We seek to summarize the information available using these variables, which are then called factors. Generally, at least two factors are taken in order to have a graphical representation of individuals and variables in the plan. 
Since most of the data is of a qualitative nature, the principal component analysis of our data requires a complete disjunctive table, since principal component analyzes are usually reserved for quantitative variables. The analysis is based on a sample of 150 NPOs created from 1992 to 2011 and on most variables in the database.

\section{Methods for Analyzing Qualitative Data}

To analyze the qualitative data, we make an AFC and an AMC (Analysis of the Simple and Multiple Correspondents) which are adapted to the analysis of the qualitative data (formatting of crossed tables or complete disjunctive tables). The factorial analysis of simple correspondences studies the connection (or the correspondence) between two qualitative variables. In this way, we demonstrate the modalities of the variables that intervene in the link and the way in which they intervene (dependence). For this, we make an AFC to process data in the form of a contingency table consisting of individuals described by two qualitative characters. In the end, we make an AMC which is a generalization of the AFC to more than two qualitative variables. The AMC is the preferred method of data analysis because it lends itself well to the analysis of questionnaires. In addition, it has particular mathematical properties and interpretation rules that differ from those of the AFC.

The principle of the AMC is identical to that of the AFC, namely the same transformation of the table into line profiles and column profiles, the same adjustment criterion with equal point weightings to the marginal profiles and the same distance Chi-square.

\section{Results}

Using a quantitative approach, we show the specific characteristics of burundian NPOs who benefit from microcredit. We provide empirical results to show how these NPOs align with the donor's constraints through some key quantitative indicators. We also show that all the indicators (qualitative and quantitative) vary according to each other to adapt to the constraints of the lessor. In our article, we show more precisely the organizational specificities and profile elements of these nonprofits.

\section{Specificities of NPOs that emerge from the sample}

In their adjustment to the requirements of MFIs, some NPOs in our sample have obvious similarities at the organizational level. The following tables show the organizational specificities that contribute to the alignment of Burundian NPOs benefiting from microcredit to the constraints of MFIs.

The majority of associations in our sample have a membership of less than 40 women. Many Burundian NPOs who benefit from microcredit have a number of men equal to zero. NPOs that have few men among their members are not recent. For example, we have a single association with only one man in a 130-member group that dates back to 1991. Two non-profit micro-credit NPOs have a large number of men (over 200) and were created as of 2000. Women are involved in all income-generating activities regardless of their proportion in their respective associations. However, we show in the table below that the proportion of women differs according to the nature of the activity. 
An important element of the socio-economic profile of Burundian NPOs benefiting from microcredit that has attracted our attention is the proportion of women in all NPOs in our sample. We find that women are involved in all income-generating activities. However, we show in the table below that the proportion of women differs according to the nature of the activity.

Table 3. Percentage of women by type of activity

\begin{tabular}{|l|l|l|l|l|l|l|l|l|l|}
\hline & Agriculture & Trade & Sewing & Education & $\begin{array}{l}\text { Motorcycle } \\
\text { riding }\end{array}$ & Hairstyle & Bus driver & $\begin{array}{l}\text { Photocopy } \\
\text { and rinting }\end{array}$ & Total \\
\hline $0-40 \%$ & 57.7 & 23.1 & 3.8 & 0.0 & 3.8 & 0.0 & 7.7 & 3.8 & 100.0 \\
\hline $41-60 \%$ & 43.2 & 50.0 & 0.0 & 6.8 & 0.0 & 0.0 & 0.0 & 0.0 & 100.0 \\
\hline More than 70\% & 21.2 & 72.5 & 3.8 & 1.2 & 0.0 & 1.2 & 0.0 & 0.0 & 100.0 \\
\hline Total & 34.0 & 57.3 & 2.7 & 2.7 & 7.0 & 7.0 & 1.3 & 0.7 & 100.0 \\
\hline
\end{tabular}

Source: Authors based on survey data

Many women do business, which is an activity with limited capital provided by microfinance institutions and allows for regular repayment.

On the one hand, $57.3 \%$ of the associations operate in the trade sector while $34 \%$ practice agriculture. On the other hand, $57.7 \%$ of associations that practice agriculture have $0-40 \%$ of women, while only $23.1 \%$ of trade associations have $0-40 \%$ of women. On the other hand, $72.5 \%$ of trade associations account for more than $70 \%$ of women, while only $21.2 \%$ of farming associations have more than $70 \%$ of women.

\section{Types of Income Generating Activities}

The income-generating activities of Burundian NPO members benefiting from microloans are very small economic activities allowing members to have a regular income. They aim to strengthen the ability of members to create activities adapted to the specificities of their needs.

We distinguish six types of income generating activities (IGA) obtained using the principal component analysis. The numbers and percentages of members engaged in these income-generating activities are presented in the following table.

Table 4. Number of members of associations benefiting from microcredit by type of income generating activity

\begin{tabular}{|c|c|c|c|c|c|c|c|c|}
\hline & $\begin{array}{l}\text { Number of } \\
\text { men }\end{array}$ & $\%$ & $\begin{array}{l}\text { Number of } \\
\text { women }\end{array}$ & $\%$ & $\begin{array}{l}\text { Total of } \\
\text { members }\end{array}$ & $\%$ & $\begin{array}{l}\text { Number of } \\
\text { NPO }\end{array}$ & $\%$ \\
\hline Activity 1: Agriculture & 806 & 41,74 & 930 & 45,95 & 1726 & 43,75 & 51 & 34.00 \\
\hline Activity 2: Commerce & 208 & 10,77 & 922 & 45,55 & 1130 & 28,64 & 86 & 57.33 \\
\hline Activity 3: Couture & 20 & 1,04 & 78 & 3,85 & 98 & 2,48 & 4 & 2.67 \\
\hline $\begin{array}{l}\text { Activity 4: Agriculture } \\
\text { as secondary activity }\end{array}$ & 42 & 2,18 & 69 & 3,41 & 111 & 2,81 & 4 & 2.67 \\
\hline $\begin{array}{lll}\text { Activity } & 5: \quad \text { Car } \\
\text { Driving } & & \\
\end{array}$ & 5 & 0,26 & 0 & 0,00 & 5 & 0,13 & 1 & 0.67 \\
\hline Activity 6: Hairstyle & 4 & 0,21 & 20 & 0,99 & 24 & 0,61 & 1 & 0.67 \\
\hline $\begin{array}{l}\text { Activity 7: } \\
\text { Motorcycle Driving }\end{array}$ & 791 & 40,96 & 4 & 0,20 & 795 & 20,15 & 2 & 1.33 \\
\hline
\end{tabular}




\begin{tabular}{|l|l|l|l|l|l|l|l|l|}
\hline $\begin{array}{l}\text { Activity 8: Photocopy } \\
\text { and Printing }\end{array}$ & 55 & 2,85 & 1 & 0,05 & 56 & 1,42 & 1 & $0 . .67$ \\
\hline Total & 1931 & 100 & 2024 & 100 & 3945 & 100 & 150 & 100 \\
\hline
\end{tabular}

Source: Authors based on survey data

Trade is practiced by the majority of NPOs who benefit from microcredit. These are small associations when compared to NPOs whose members practice agriculture.

In the end, a classification of activities highlights a typology of Burundian NPOs benefiting from microcredit in six main groups.

Activity 1: Agriculture

The first category identified is 51 , or $34 \%$ of NPOs who benefit from microcredit whose members practice agriculture. The most cultivated products are: banana, tubers (sweet potato, cassava, colocase, potato), legumes (beans, peas), cereals (maize, rice, wheat, sorghum, finger millet) and vegetables and fruits. The elements financed are, among other things, the means of production such as agricultural inputs (improved seeds and fertilizers), agricultural tools and the payment of labor. Agriculture is not only exercised by peasants alone. Indeed, the fourth activity also covers associations whose members are primary school teachers and farmers at the same time.

Members of NPOs who benefit from microcredit need slightly higher loan amounts to carry out their income-generating activities. They also and above all need more or less flexibility on repayment terms. In addition, in the particular case of farmers, the members of these NPOs need a supply adapted to different agricultural cycles to buy seeds and inputs. Unfortunately, short-term credit (less than a year in our case) is not only unsuitable for the farmer but also for a trader who wants to buy a stock of goods. In fact, $94.1 \%$ of associations whose members are farmers are almost exclusively in rural areas.

Activity 2: Trade

The second category of activity brings together $57.3 \%$ of the NPOs in our sample. For commercial activities, it is small business in general. Most often, members of non-profit organizations sell fruits and vegetables or charcoal.

Merchants benefiting from micro-loans are not recognized in the commercial register. Most often, they buy foodstuffs that they resell as they are on market days. Unfortunately, we noticed that there is a majority of traders who can not afford a booth, because trade is exercised much more in urban than in rural areas

Activity 3: Sewing

In Burundi, we distinguish the craftsmen of the city on the one hand and those who make crafts as main activity on the other hand. In the latter case, craft is not a secondary activity that complements agriculture.

It's true that Burundian artisans often apply for individual loans, but we still met some isolated tailors who gather in workshops to benefit from group microcredit. The credit 
granted allows them to buy sewing machines and their accessories.

The day-to-day life of the micro-credit fashion designer revolves around two activities: the creation of models and the retouching of clothes. Different stages punctuate his work: customer measurements, pattern drawing, cutting, then assembly and finishing. The couturiers benefiting from microcredit rent most often a workshop in large cities.

Activity 4: Car and Motorcycle Driving

The bus or motorcycle drivers we interviewed are engaged in full-time driving activity. They often drive for others. But there are motorcycle drivers who use their own gear. Car drivers and conveyors, on the other hand, do not own the buses they drive or transport. Associations whose members are either motorcycle drivers or bus drivers are $100 \%$ urban.

Associations of motorcycle drivers are often very small. They prefer to be few to avoid conflicts that may arise especially when repaying the loan. Only one association of drivers and bus drivers that we interviewed is very large.

Activity 5: The hairstyle

The fifth category of activity consists of $0.67 \%$ of the NPOs in our sample. All hairdressers who benefit from microcredit carry on their activities in a hairdressing salon. Members of this category of nonprofits ask for microcredit to buy the equipment to open a hairdressing salon. These hairdressers are limited to the haircut and are mixed hairdressers.

Activity 6: Photocopying and Printing

The last category concerns $0.67 \%$ of the NPOs in our sample. Among those who photocopy and print, there are those who manage to buy a photocopier or printer and buy them used. Often, their services are not of good quality. The clients must provide their own sheets and pay the cost of photocopying or printing.

\section{Discussion of the Results}

In marketing, it is customary to schematize the evolution of markets or business sectors in four phases. Each is characterized by a pace of change in demand. So we usually hear the product life cycle and not the life cycle of an activity. The product life cycle looks at the normal evolution of the company's products in their market.

The concept of life cycle is of great interest to any business (Porter, 1991). This is why we analyze the life cycle of the activities of burundian NPOs who benefit from microloans. We suggest that a revenue-generating activity is a function of the supply of microcredit. In fact, thinking about the strategic adjustment of microcredit beneficiary NPOs requires understanding the extent of the need for resources at each stage of the exercise of their activities.

In addition, the promotion of income-generating activities is a sign of the emergence of a new conception of the market based on the valorization of associative activism as income earner.

We distinguish three stages: creation, growth and stabilization. To start an income-generating 
activity, the majority of the promoters apply for a loan. Indeed, the financing aspect dominates in the creation stage. When the income generating activity (IGA) is in a growth stage, the rate of change in the demand for credit accelerates. The life cycle of an IGA therefore induces particular strategies of members to achieve financial equilibrium. However, we must emphasize that the length of each of these phases is much more dependent on the activities of members of NPOs who benefit from microcredit.

A careful examination of the life cycle of an income-generating activity is an important step for us in analyzing the adjustment strategies of non-profit micro-credit NPOs. In fact, this analysis requires knowing the major trends in financial equilibrium. Once we know its evolution, we must seek to understand the reasons that can explain these major trends. In our analysis, we mainly look at two aspects: the activities and resources of NPOs who benefit from microcredit.

\section{Objectives of microcredit beneficiary NPOs and their organizational specificities}

The survival of Burundian NPOs who benefit from microcredit, which is the subject of our study, does not make it possible, at first glance, to apprehend the link that exists with their objectives. In other words, the fear for survival and the search for exit routes for members of these NPOs does not appear to be related to the objectives of their respective members. Yet, in our view, it is linked to this variable through an all-or-nothing logic. Either the NPO is able to grow and set goals through the MFI's funding that allows NPO members to engage in an income-generating activity and its future is optimistic in this case. Otherwise, NPO does not find sufficient resources, so cannot consider projects and in this case fears for survival are manifested.

Finally, the link between survival and objective is clear for these NPOs because it is their objectives that are the main interest. In order to carry out their income-generating activities, NPOs benefiting from microcredit have specific survival objectives. We summarize this through the table below (table 5).

Table 5. Objectives of NPOs Benefiting from Microcredit in Burundi

\begin{tabular}{|l|l|l|}
\hline Goal & Number of NPOs & Percentage \\
\hline Social assistance & 15 & 10,0 \\
\hline Financial assistance & 5 & 3,3 \\
\hline Production of goods and services & 52 & 34,6 \\
\hline Others (satisfaction of needs) & 78 & 52,0 \\
\hline Total & 150 & 100,0 \\
\hline
\end{tabular}

Source: Authors from the survey data

As mentioned above, the overarching goal of these NPOs is to meet the physiological needs of members. In fact, members say that earnings from income-generating activities serve to cover their physiological needs. Thus, the NPO beneficiary of microcredit achieves this objective through the production of goods and services or through trade which allows it to have easy and quick profits.

In our analysis of how microcredit-enabled NPOs operate, we show that the activity, size, 
structure and objectives of the NPO are very much linked to the survival objective. However, the latter is one of the indicators of the organizational effectiveness of these NPOs in its new dimension (survival). These first three variables influence the internal organization, and thus the organizational efficiency, of burundian NPOs that benefit from microcredit. Thus, we show that the members of these NPOs have achieved their objective because they perform an activity closely linked to their objectives. We recognize that NPOs have a small size, a large proportion of women and are concerned about the satisfaction of physiological needs.

For this purpose, we divide the "main objective" into four objectives of Burundian NPOs benefiting from microcredit. Four objectives, namely: satisfaction of primary needs, production of foodstuffs and social and financial assistance, measure the level of organizational efficiency. The objective of the loan, in four levels of representation, emphasizes the importance of the survival strategies of NPOs who benefit from microcredit in their organizational efficiency.

These survival strategies of burundian NPOs are the satisfaction of primary needs and the production of food products or both. We thus suggest that these survival strategies are determining factors in achieving the organizational objectives of these NPOs.

\section{Analysis of the profiles of the members of the NPOs benefiting from microcredit in Burundi}

In our analysis of the profile of Burundian NPOs benefiting from microcredit, we subscribe to a statistical approach using quantitative data. This is an important issue as it provides an opportunity to explain the organizational parameters of the members of these NPOs.

The basic principle of PCA is to obtain an approximate representation of clouds in a low-dimensional subspace (1, 2 or 3 ). But this reduction is not done by elimination or partial selection of the initial variables. It is based on the construction of new synthetic variables obtained by combining the initial variables using factors. In these conditions, we are satisfied with a geometric representation in a plane.

Assuming that there are $\mathrm{p}$ active variables $\mathrm{X} 1 ; \mathrm{X} 2 ; \ldots ; \mathrm{X} \mathrm{p}$ observed on a population of $\mathrm{n}$ individuals, we denote by $\mathrm{X}$ ij the value taken by the variable $\mathrm{X} j$ for the individual $\mathrm{i}$.

To fully explore the clouds obtained by geometric representations, we need a space of dimension four. After the PCA, Table 6 is obtained.

Table 6. Table of eigenvalues for the PCA

\begin{tabular}{|l|c|c|c|}
\hline & Own Values & Percentage of variance & Percentage of cumulative variance \\
\hline Component 1 & 1,610 & 40,238 & 40,238 \\
\hline Component 2 & 0,932 & 23,303 & 63,541 \\
\hline Component 3 & 0,869 & 21,713 & 85,254 \\
\hline Component 4 & 0,590 & 14,746 & 100,000 \\
\hline
\end{tabular}

Source: Authors based on survey data

A factorial axis restores some of the initial information contained in the data. This piece of information is measured by the eigenvalue associated with the axis director vector. The 


\section{$\triangle 1$ Macrothink}

Business and Economic Research ISSN 2162-4860 2018, Vol. 8, No. 3

number of factorial axes following the PCR is equal to four (number of quantitative variables).

La dimension 1 permet d'expliquer 40,24 \% (voir colonne pourcentage) de l'information contenue dans le tableau des données brutes. Autrement dit, 40,24 \% des disparités entre les individus peut être interprétée sur le premier axe factoriel. La dimension 2 restitue 23,30\% de ces disparités, etc. La dernière colonne de ce tableau indique que le plan constitué des deux premiers axes (plan $(1,2)$ ) conserve $63,54 \%$ de la dispersion du nuage.

In our analysis, we considered dimensions 1, 2 and 3. In general, a share of inertia between 60 and $80 \%$ is sufficient according to Morineau and Aluja-Banet (1998).

In factorial correspondence analysis, the raw table is not analyzed directly. The data is transformed into profiles. We thus obtain two tables of profiles: a table of profiles columns and a table of profiles lines.

Table 7. Table of results resulting from the analysis of the line profile

\begin{tabular}{|l|l|l|l|l|l|l|l|l|l|l|}
\hline & iner *1.000 & Dim 1 & CTR & Cos $^{2}$ & Dim 2 & CTR & Cos $^{2}$ & Dim 3 & CTR & Cos $^{2}$ \\
\hline Social assistance & 297,431 & 0,616 & 4,835 & 0,127 & 1,611 & 85,116 & 0,872 & 0,014 & 0,049 & 0,000 \\
\hline Financial assistance & 53,876 & 0,640 & 1,739 & 0,253 & $-0,354$ & 1,374 & 0,078 & 1,040 & 93,554 & 0,669 \\
\hline Production of goods and services & 512,341 & $-1,216$ & 65,325 & 1,000 & $-0,009$ & 0,008 & 0,000 & $-0,001$ & 0,000 & 0,000 \\
\hline Satisfaction of needs & 264,016 & 0,651 & 28,101 & 0,835 & $-0,281$ & 13,502 & 0,156 & $-0,069$ & 6,397 & 0,009 \\
\hline
\end{tabular}

Source: Authors based on survey data

As an axis is interpreted both by the line modalities and by the column modalities, the profiles best represented on one axis illustrate this axis well because they make it possible to explain its meaning. The interpretation of an axis is therefore based primarily on the contributing points that explain its positioning. These points are divided into two parts: on the one hand, the negative coordinate points, and on the other hand, the positive coordinate points.

If, among these points, there are some who have a $\operatorname{Cos} 2$ that is both more important than the others and of a high level, we must pay particular attention to these points. The profiles associated with them have a direction very close to that of the factorial axis and clearly highlight what the direction of elongation of the cloud represented by this axis means.

Table 8. Table of Results Arising from the Analysis of the Column Profile

\begin{tabular}{|l|l|l|l|l|l|l|l|l|l|l|}
\hline & iner *1.000 & Dim 1 & CTR & Cos2 & Dim 2 & CTR & Cos2 & Dim 3 & CTR & Cos2 \\
\hline Agriculture & 496,526 & $-1,208$ & 63,282 & 1,000 & 0,013 & 0,019 & 0,000 & $-0,022$ & 0,445 & 0,000 \\
\hline Commerce & 259,150 & 0,657 & 31,540 & 0,954 & $-0,140$ & 3,678 & 0,043 & $-0,032$ & 1,511 & 0,002 \\
\hline Couture & 40,962 & 0,205 & 0,143 & 0,027 & $-0,419$ & 1,537 & 0,114 & 1,148 & 91,23 & 0,858 \\
\hline Education & 240,000 & 0,695 & 1,644 & 0,054 & 2,917 & 74,45 & 0,946 & 0,070 & 0,339 & 0,001 \\
\hline Motorcycle Driving & 6,154 & 0,735 & 0,459 & 0,585 & $-0,510$ & 0,568 & 0,281 & $-0,351$ & 2,128 & 0,133 \\
\hline Hairdressing & 60,000 & 0,695 & 0,411 & 0,054 & 2,917 & 18,61 & 0,946 & 0,070 & 0,085 & 0,001 \\
\hline Car Driving & 12,308 & 0,735 & 0,919 & 0,585 & $-0,510$ & 1,136 & 0,281 & $-0,351$ & 4,256 & 0,133 \\
\hline Others & 12,564 & $-1,373$ & 1,602 & 1,000 & $-0,016$ & 0,001 & 0,000 & 0,003 & 0,000 & 0,000 \\
\hline
\end{tabular}

Source: Authors based on survey data 


\section{Mll Macrothink}

Business and Economic Research

ISSN 2162-4860

2018, Vol. 8, No. 3

This transformation also stems from the AFC's goal of studying the link between the two characters across the gap between profiles. Thus, all the reasoning is done in terms of profiles and the inertia is proportional to the connection between the two characters. This inertia translates into AFC the structure of the table.

However, since graphics are projections, apparent proximities may not correspond to any real proximity in space. In PCA, and in general in all the methods of factorial analysis, there are statistical elements which make it possible to unmask these false proximities and to interpret with more rigor and precaution the information delivered by the graphical representations. These elements are called aids to interpretation. The most used are the cosine squared (COS2) and the contribution (CTR).

What is the impact that the size of these NPOs can have on their effectiveness? Burundian NPOs, often small, have a strong membership base. This is the main characteristic of this type of NPO that may seem trivial but is of decisive importance. This importance comes from the fact that their members determine the objectives and benefits themselves and participate in the production of these benefits.

The socio-economic characteristics of Burundian NPOs benefiting from microcredit have significant explanatory power on their organizational efficiency. But, the divergence of research results is more marked with certain indicators, in particular their seniority and their size. While a large size is a significant indicator for some in the sense of greater performance, we find in our study that young NPOs are rather more successful.

The analysis of the profile of microcredit beneficiary NPOs makes it possible to identify three variables that most strongly structure the associative field of Burundi. These variables are the structure of the association, its purpose and activities. They influence their organizational effectiveness. From the principal components analysis and the multiple correspondence analysis, we analyze the variables of the NPOs who are beneficiaries of microcredit, close or not to the objective of survival.

The operationalization of the five theoretical dimensions of organizational effectiveness below allows us to identify the following three profiles:

Table 9. Three strategic adjustment profiles of Burundian NPOs benefiting from microloans

\begin{tabular}{|l|l|l|l|l|l|}
\hline & Internal Organization & Effectiveness & Legitimacy & Sustainability & Survival \\
\hline Profil 1 & More than 70\% of women & Economic objective & Small size & Commerce & Service Provision + Trade \\
\hline Profil 2 & From 41 to $69 \%$ of women & Economic objective & Middle size & Service Provision + Trade & Service Provision + Trade \\
\hline Profil 3 & From 0 to $40 \%$ of women & Social Objective & Big size & Agriculture & $\begin{array}{l}\text { Production of goods } \\
\text { and services }\end{array}$ \\
\hline
\end{tabular}

Source: Authors from the variables of our study

The analysis in the table above shows that when the five dimensions of the profile belong to the same rank, that is, a large proportion of women grouped in a small or medium-sized trade association linked with an economic objective and the satisfaction of physiological needs, the level of alignment is described as strategic. Compared to the dominant gender, we notice that associations with fewer women among their members practice agriculture. Those with more 
women are involved in trading. These two types of activities contribute to the survival of the members of these NPOs.

Each profile is described by the conjunction of the characteristics of its elements. Since no individual outside of a profile has its characteristics, our classification seems quite complete. Thus, the adaptation of micro-credit beneficiaries that best adapt to the constraints of the lessor are characterized by: a small size, investment in agriculture and trade. Also, participative dynamism is strongest in associations that have a large proportion of women. This is not surprising, as women in poor families are more concerned about the survival of their families, whether heads of households or not. Also, it should be added that poor families are large compared to those who are better off, which requires an extra effort on their part to be able to feed their families.

We find that these NPOs adapt to the lender's requirements in three main ways. On the one hand, the operating methods of the members of these NPOs show their attachment to the trade whatever their location. In fact, agriculture is a poor performer, and agricultural yields are falling as a result of rapid population growth, fragmentation and overexploitation of the resulting land. To this is added the unfavorable weather conditions that worsen the very fragile socio-economic situation of the members. In addition, the structure of these NPOs reveals very small sizes. Finally, to survive, almost all the NPOs that are the focus of the study have as their primary mission the production of primary goods or the satisfaction of physiological needs or both.

\section{Conclusion}

In the analysis that have been done on the associative phenomenon, it is customary to distinguish two types of presentations that can be opposed. On the one hand, this is general information on diversity and the contribution of associations to economic development. On the other hand, they are evaluation studies of associations in a given country. Our analysis focuses on the profile of Burundian NPOs receiving funding from a microfinance institution. To analyze the profile of microcredit-assisted NPOs, we re-read the data using either principal component analysis or multiple correspondence analysis as appropriate. We first explain the specificities that emerge from the sample. We then show that the income-generating activities allow them to reach their end. Indeed, the provision of loans allows members of burundian NPOs who are beneficiaries of microcredit to create income-generating activities. In this case, the term microcredit does not only have a financial interpretation. It also contributes to the satisfaction of the physiological needs of the members of these NPOs. In concrete terms, we arrive at a coherent typology of NPOs that highlights the discriminatory aspect of "the nature of the activity carried out". The analysis of the data collected shows that the income-generating activity seems to influence the other dimensions of the profile. In other words, from each activity flows a well-defined profile that ensures a certain adaptation for the NPO beneficiary of a microcredit.

\section{References}

Atkinson, A., \& Waterhouse, J. (1997). A Stakeholder Approach to Strategic Performance 
Measurement. MIT Sloan Management review, 38(3), 25-38.

Bureau, D., Michel, M., \& Nicolas, S. (2010). Mesurer la performance de la gestion publique à la lumière de l'analyse économique. Revue française des affaires sociales, 1(1-2), 89-104.

Cagliano, R., Blackmon, K., \& Voss, C. (2001). Small firms under MICROSCOPE: international differences in production/operations management practices and performance. Integrated manufacturing systems, 12, 469-482. https://doi.org/10.1108/EUM0000000006229

Coase, R. H. (1995). The nature of the firm: meaning. Repéré à

http://down.cenet.org;cn:upfile/45/2006 123111157127.pdf

Gauzente, C. (2000). Mesurer la performance des entreprises en l'absence d'indicateurs objectifs: quelle validité? Analyse de la pertinence de certains indicateurs. Finance Contrôle Stratégie, 3(2), 145-165.

Gavard-Perret, M. L., Gotteland, D., Haon, C., \& Jolibert, A. (2012). Méthodologie de la recherche en sciences de gestion: Réussir son mémoire ou sa thèse. $2^{\text {ème }}$ édition. Paris: Pearson.

Ghauri, P., \& Grønhaug, K. (2002). Research methods in business studies. A practical guide. $2^{\text {nd }}$ edition. London: Prentice Hall.

Henderson, J., \& Venkatraman, N. (1999). Strategic alignment: Leveraging information technology for transforming organizations. IBM systems journal, 38(283), 472-484. https://doi.org/10.1147/SJ.1999.5387096

Herman, R. D., \& Renz, D. O. (2004). Advancing nonprofit organizational effectiveness: research and theory: nine theses. Nonprofit management and leadership, 18(4), 399-415. https://doi.org/10.1002/nml.195

Kaplan, R. S., \& Norton, D. P. (2001b). Transforming the balanced scorecard from performance measurement to strategic management. Accounting horizons, 15, 147-160. https://doi.org/10.2308/acch.2001.15.2.147

Kihn, L. A. (2005). Comparing performance measurement approaches in accounting research. Finnish journal of business economics, 2, 143-184.

Lawrence, P. R., \& Lorsch, J. W. (1967). Differentiation and integration in complex organizations. Administrative Science Quarterly, 12, 1-47. https://doi.org/10.2307/2391211

Lawrence, P. R. (1993). The contingency approach to organizational design in Robert, T.G. (Ed.) (1993). Handbook of organizational behavior. New-York: Marcel Dekker, 9-18.

McAdam, R., \& McKeown, M. (1999). Life after ISO: An analysis of the impact of ISO 9000 and total quality management on small businesses in Northern Ireland. Total quality management, 10, 229-241. https://doi.org/10.1080/0954412997974

Middleton, M. (1987). Nonprofit boards of directors: Beyond the governance function, in Walter W. Powell, W.W. (1987) (ed.). The Nonprofit sector: A research handbook. New 
Haven: Yale University Press: 141-153.

Mintzberg, H. (1982). Structure et dynamique des organisations. Paris: Editions d'organisations.

Morineau, A., \& Aluja-Banet, T. (1998). Analyse en composantes principales. Paris: CISIACERESTA.

Otley, D. T. (1980). The contingency theory of management accounting: achievement and prognosis. Accounting, organizations and society, 5, 413-428.

https://doi.org/10.1016/0361-3682(80)90040-9

Porter, M. E. (1991). Towards a dynamic theory of strategy. Strategic management journal, 12, 95-117. https://doi.org/10.1002/smj.4250121008

Saidel, J. R. (1989). Dimensions of interdependence: The state and voluntary-sector relationship. Nonprofit and voluntary sector quarterly, 18(4), 335-347.

https://doi.org/10.1177/089976408901800405

Schumpeter, J. A. (1935) in Anstett, J.-J. (1999) (trad.). Théorie de l'évolution économique. Paris: Librairie Dalloz.

Sicotte, C., Champagne, F., \& Contandriopoulus, A. P. (1999). La performance organisationnelle des organismes publics de santé. Ruptures, revue transdisciplinaire en santé, 6(1), 34-46.

Sila, I. (2007). Examining the effects of contextual factors on TQM and performance through the lens of organizational theories: An empirical study. Journal of operations management, 25, 83-109. https://doi.org/10.1016/j.jom.2006.02.003

Smith, S. R., \& Lipsky, M. (1993). Nonprofits for Hire: The welfare state in the age of contracting. Cambridge, MA: Harvard University Press.

Theuvsen, L. (2004). Doing better while doing good: motivational aspects of pay-for-performance effectiveness in nonprofit organizations. Voluntas: International journal of voluntary and nonprofit organizations, 15(2), 117-136.

https://doi.org/10.1023/B:VOLU.0000033177.16367.e3

Thiétart, R. A. (1999). Méthodes de recherche en management. Paris: Dunod.

Walley, K. (2000). TQM in non-manufacturing SMEs: evidence from the UK farming sector. Total quality management, 18, 46-61. https://doi.org/10.1177/0266242600184003

Williamson, O. E. (2002). The theory of the firm as governance structure: from choice to contract. Journal of economic perspectives, 16(3), 171-195.

https://doi.org/10.1257/089533002760278776 


\section{Copyright Disclaimer}

Copyright for this article is retained by the author(s), with first publication rights granted to the journal.

This is an open-access article distributed under the terms and conditions of the Creative Commons Attribution license (http://creativecommons.org/licenses/by/3.0/). 